\title{
Continued increases in military and police spending can lead to economic collapse
}

\author{
Muhammad Jawad Sajid ${ }^{1, *}$ \\ ${ }^{1}$ School of Management, Xuzhou University of Technology, Xuzhou, China.
}

\begin{abstract}
Human defence expenditure has increased due to the need for permanent military and police forces, which has led to the creation of a perpetual fear industry. The so-called fear industry refers to the industry created due to real or perceived fear, without this fear, the industry cannot be created. Most defence economic studies (both military and police) focus on various empiric aspects such as opportunity costs, GDP growth, public expenditure and defence industry taxes. However, this study focuses on the development and explanation of the theory behind the creation and death of this preputial industry of fear. This study also presents the concept of social GDP and free GDP, which can help to present the long-term economic effects of the reduction or possible elimination of defence spending by national governments. Decreased defence spending generally has economic and social benefits for the general public. In the long run, rising costs of the defence industry (military and police spending, etc.) and other miscellaneous social issues can lead to civil unrest or possible civil wars, which can have a devastating impact on global economies in the long run. It is therefore in the interests of global economies to begin to reduce expenditure, to seek cheaper and more acceptable alternatives, and eventually to get rid of these fear-based expenditures.
\end{abstract}

\section{INTRODUCTION}

\subsection{Background and Related Work}

Man's history is filled with fear of war and actual war. Particularly in the aftermath of the Korean War, the creation of a military industrial complex in the United States has seen an enormous amount of physical and monetary resources exhausted by the war machine. After this war, the private industries continued to produce military weapons in the Cold War with the (former) Soviet Union, before the Korean War, the private industries had returned to "civil production" after the wars had ended [1]. At the same time, the world also spends a significant amount on criminal justice organizations, during 1997 (inflated to 2004 prices) the expenditure on the criminal justice system amounted to around $\$ 424$ billion, which almost equals to half of the $\$ 812$ billion global military expenditure, with some $62 \%$ of the expenditure on criminal justice coming from the police department [2].

If we look at the example of the most advanced nation in the world i.e. the USA, we will see that not only both its military and policing expenditures are increasing but also the US public's dissatisfaction with the increase in spending and violence (wars and police brutality) is also growing. The US, the world's largest military spender [3] has a total budget of $\$ 4.7$ trillion in 2020 , with a budget deficit of $\$ 1.1$ trillion anticipated, a defence budget of $\$ 0.73$ trillion, almost $70 \%$ of the overall 2020 budget deficit (based on fiscal year 2020, budget of the U.S. government [4]). The US public has been seeking a decrease in US military spending and using the additional funds generated from reductions in military spending on miscellaneous welfare projects (see for example [5] and [6]). At the same time, we are seeing an increasing number of protests against the so-called U.S. perpetual wars, which are sometimes blamed on profit incentives for the military industrial complex, leading to ever-increasing military spending by the U.S. government (see for example [7-8]).

As per the "U.S. Department of Justice Bureau of Justice Statistics" from 1982 to 2006, the government's expenditure on police services increased fourfold [9, p.1]. In Mesa, Arizona, increased expenditure on the police department was mainly financed by the introduction of a special' quality-of-life tax' in 1997, which expired in 2008 [9, p.6]. In 2007, the Mayor of the City of Los Angeles promised an increase in the number of "sworn officers" and the price for this increase in expenditure to be recovered from the increase in "trash collection fees" [9, p.16]. In addition to the financial cost, there has been growing public criticism and dissatisfaction with the police department. Police departments in the developed world, for example, have been accused of racism, discrimination, violence, etc. [10-12]. The use of deadly force by the U.S. police and the widespread use of the "stop, question, and frisk" approach in New York City has heightened public concern about the increased use of hostile strategies that have an impact on the "rights" and "privacy" of innocent people [13, p.9308]. Violent

${ }^{*}$ Corresponding author. Email: jawad.jaws@outlook.com 
protests and current curfews across cities in the United States following the death of unarmed African-American citizen George Floyd during a police arrest in Minneapolis on 25 May 2020 are yet another example of growing public concern and dissatisfaction with police racial profiling and excessive use of lethal force [14-15]. The severity of the protests in Washington DC even forced President Trump to take refuge in a bunker in the White House [16].

The perpetual fear industries are created out of the perceived or actual constant or preputial fears (threats) of the society. These industries can be defined as those industries which cannot exist in the absence of fear of the societies i.e. the products and services of these industries are not required if the fear diminishes. For example, the military (defence) industry, without the fear of war, the societies will not allow the allocation of resources to the military industries. Because the military hardware or services directly has a huge opportunity cost in terms of its effect on resource allocation, taxes (leading to reduced income for private consumption and investment), reduced welfare and infrastructure projects, and increased governmental role etc. Excessive military expenditure reduces the supply of "residual" production resources i.e. labour and capital available for the "private and nondefence public investment" and thus weakening the economy [17, p.51]. Contrarily, reduced military expenditure will lead to greater investment and economic progress [17]. Secondly, it also directly affects the concept of free market economies which is desirable in the long run. By "reducing the role of the government" the common welfare of all can be achieved [18, p.11]. Thirdly, many nations have turned to deficit financing to finance their long run fear industries which can lead to even more taxes and hyperinflation in the future. The resources sacrificed (traded off) to the long run fear industry (like the military and other law enforcements) could be employed to increase the productive capacity of essentials (like food, clothing, medical and housing etc.) and luxurious products etc. and the additional income (through reduction in taxes) can be reinvested thus doubling the opportunity cost of the long-run fear industries. In the long run or very long run, the rational economies will realize and eliminate this irrational waste of resources. A rational society can achieve this goal by eliminating irrational warfare, thereby eliminating the need for a longterm fear industry.

\subsection{Our Contribution}

The novelty of this paper is summarized through the following points. First of all, this study clearly defines the theory behind the birth and the death of the long-term fear industries. The paper clearly presents why the defence industry (military and local law enforcement) are created and why governments need to lower their defence spending and eventually get rid of defence industry (preputial fear industry). Second, the literature on the economic effects of the military and police industry fails to describe the theory behind the creation and the death of this long run fear industry. Most of the related literature focuses on the different empirical aspects of this industry's economic impacts [9], [19-21], [23], [27], [28]. Rather than the theory behind the birth and the eventual death of the defence (fear) industries. Fourth, the conventional GDP is not capable to present the effects of the long run fear industry (defence industry) on the output. The reason is that the usual (real) GDP also includes the defence goods and services when estimating the GDP of an economy. In this study I will also introduce the concept of the (real) SGDP (social gross domestic product) which presents the GDP of a nation without its defence expenditure. And the concept of FGDP (free gross domestic product) which presents the GDP of a free market economy i.e. the GDP of a country (economy) minus all of its governmental expenditures. The larger the defence expenditure the more negative impact it will have on the SGDP and FGDP. On the other hand, a decrease in the defence expenditure will cause the SGDP and FGDP of a nation to move in the positive direction. And when the additional resources available by decreasing or even eliminating the long run fear industries are utilized on alternative it will further increase the value of SGDP and FGDP and will allow the long run supply curve to move towards its optimal production capacity. The difference is that under the mixed economies these additional resources will most likely be reallocated to other public welfare or infrastructure by the government (presented through the SGDP). And under free economies these resources will be utilized by the private business for different projects (presented through the FGDP). Appendix section presents the mathematical modelling for the estimation of SGDP and the FGDP respectively.

\subsection{Paper Structure}

The rest of the paper is organized in the following manner. Section 2 presents the Results: theory and model of this study. Where section 2.1 presents Theory: increased fear spending (military and police) can lead to economic collapse and section 2.2 presents Model: explain the economic incentives to eliminate the industry of preputial fear. Section 3 presents Conclusion and limitations where 3.1 presents Conclusion and 3.2 presents limitations of our work. Finally, appendix section presents the methodology for the estimation of Social gross domestic product (SGDP) and Free gross domestic product (FGDP).

\section{Results: theory and model}

\subsection{Theory: increased fear spending (military and police) can lead to economic collapse}

Nobel laureate Milton Friedman in a lecture (Q\&A session) at "University of Rochester" [29, p.20] expressed that a country's economy has a tax take "break-point" and this break-point is different for different nations. The huge allocation of resources to defence industry will result in the collapse or decline of economies in the long run even before reaching their full potential. In the long run either the governments will fail to continuously deficit finance this preputial fear industry, because eventually the hyper- 
inflation rate will swing out of control. Or, the public will simply refuse to pay the additional taxes, which does not result in the betterment of public welfare or infrastructure (non-defence investment), and is a cause of wide-spread death and destruction. This second possibility is based on the fact that in economics people are generally supposed to be rational, so rational people will not agree to make irrational investment or spending in the form of taxes paid for the irrational defence industries. Thirdly, the elimination of the long run fear industries will ensure less government intervention and control thus leading the economies towards free markets in the long run. All of these factors will increase public demand for the reduction and eventual elimination of the defence (preputial fear) industry. The failure of governments to meet this increased public demand can lead to civil disobedience or even civil war, which in turn ensures that, in the long run, we can expect to have perpetual fear (defence) industry free economies.

The second comparatively slower phase will be the elimination of the local public law enforcement products and services industries (e.g. the elimination of the police departments). In the long run the rational economies will understand that they can save much more by reducing and finally eliminating the local preputial fear industries (law enforcement industry), and the additional savings and the increased earnings can be invested specifically for the rehab of the criminals, and generally for public welfare, infrastructure development and increase private investment. The policing just like the defence industry also has significant opportunity cost in terms for resources allocation, and increase government expenditure (mostly financed through increase taxation and deficit financing). In addition, lawsuits against police misconduct also have a huge financial cost, often costing city governments millions of dollars on an annual or even monthly basis [20]. The bottom line is that rising costs and dissatisfaction with the police services will push rational societies (people) to look for other effective alternatives that will involve reduced government interference and greater involvement of societies and the private sector, which, in turn, will ensure that these services are available at more effective competitive prices or are freely available through voluntary public participation. In the long run, this will move economies towards free market economies. There are several alternatives to traditional law enforcement [30], [31], some of which have a positive impact on the economy, public trust and greater value in the efforts of police departments to engage societies [32]. While the creation of fully society-based voluntary organizations (without the involvement of any law enforcement agencies) such as the "Citizens Local Alliance for Safer Philadelphia (CLASP)" resulted in 75\% less crime in city districts under CLASP surveillance compared to police-controlled districts [30, p.12].

Therefore, a more rational long run economy, less prone to riots, civil disobedience and even possible civil wars leading to collapse or recession in long run, is a preputial fear (defence) industry free economy. Of course, I'm not talking about the current economies, where war and crimes are unfortunately inevitable. Thus forcing economies to make irrational investment and allocation of the resources in the preputial fear industries. In the long run, the rational economies (people) will realize the presence of this irrational expenditure in the industry of fear (military and police industries), which in the first stage will be achieved by reducing and finally eliminating the products and services of the industry of fear, by means of peace with other economies (countries) and by using alternatives to the police. In order to eliminate the need for military industry, long-term rational economies (people) may also decide to remove border restrictions, eliminating the need for military industry and services in the long run. It is therefore high time that global leaders took these factors into account, and instead of continuing to increase local and external defence expenditure, they began to reduce these expenditures and finally eliminate these irrational expenditures. Otherwise, in the long run, rational people will not allow this continuous increase in defence spending by taking matters into their own hands, in the form of civil disobedience and civil war, to get rid of these preputial fear (defence) industries.

\subsection{Model: explain the economic incentives to eliminate the industry of preputial fear}

Figure 1 presents the model for the long run fear industry. The long-term economy is usually defined on the basis of supply, i.e. in the long run the increase or decrease in demand prices only affects the rate of inflation, the actual output of any economy is increased by shifting the supply curve through technological improvement, efficiency, resource increase, etc. The traditional approach does not, however, separate the role of the long-term or very longterm fear industry in the economy, i.e. the effects of the increase or decrease in output (supply quantity) of longterm fear industries. In figure 1 the $\mathrm{Q}_{0}$ represents the original (initial) long run supply quantity (curve) of an economy. Which will be shifted to the left in the (very) long run, because the rational society will realize that defence expenditure, even if it contributes to GDP, is not a real fixed investment that gives them any real benefit (increased non-defence expenditure or private investment), but rather an unnecessary overhead that needs to be eliminated. The current GDP definition includes the products and services of the fear industry (including military and local law enforcement agencies). Here, I have developed new terms of the Social Gross Domestic Product (SGDP) and Free GDP (FGDP) to describe the impact of defence expenditure on aggregate supply. The SGDP is equal to GDP minus defence expenditure and the FGDP is equal to the GDP minus government expenditure.

In the long run, unsustainable deficit financing, tax breakpoints, and the desired increase in non-defence expenditure and private investment that can lead to civil unrest and even civil war will force the governments to reduce expenditure, shifting the original aggregate supply curve $\mathrm{Q}_{0}$ to the right, and finally the elimination and reallocation of additional resources (acquired from eliminating long-term fear industry) will shift the $\mathrm{Q}_{0}$ curve to the $\mathrm{Q}_{1}$. Here, $\mathrm{Q}_{1}$ represents the SGDP (or FGDP) of an economy without the existence of the long run fear 
industry. Any increase in defence expenditure (i.e. investment in technology, additional allocation of resources) will shift the curve to the left, e.g. to $\mathrm{Q}_{2}$, again factors such as unsustainable deficit financing, tax breakpoint, and the desired increase in non-defence expenditure and private investment will trigger rational economies to reduce log-run fear spending, thereby restoring the SGDP (or FGDP) supply curve to original $\mathrm{Q}_{0}$ and finally to $\mathrm{Q}_{1}$. In the long run, this continuous fear expenditure (military and police) will initially be significantly reduced and, in the ideal (optimal) situation, will be completely eliminated in the developed world. Following this, other developing and underdeveloped nations will also realize this fact, which will lead to a complete global extinction of the industry of fear in the long or very long term. In the long run, therefore, rational societies will understand the unnecessary irrational expenditure on this preputial fear industry and will refuse to pay the additional price for its existence. This additional price is usually paid in the form of taxes, deficit financing (which leads to inflation), foreign loans etc. And in the form of the opportunity cost of allocating human and fixed assets resources to the long-term fear industries. This, in turn, reduces the amount of production resources and funding available for non-defence and private investment.

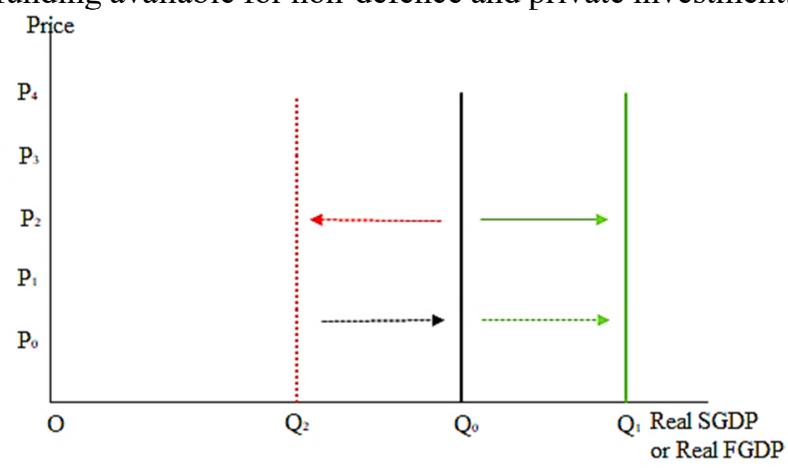

Fig 1. A model of economic incentives to eliminate the industry of fear. Y-axis presents the price and $\mathrm{X}$-axis presents the real SGDP or real FGDP. Q 0 presents the original supply curve, $\mathrm{Q}_{1}$ presents the supply curve in case of the elimination of the long run fear industry, $\mathrm{Q}_{2}$ presents any arbitrary increase in the amount of fear industry (military and police) spending. The arrow heads present the direction of the shifts in the supply quantities (curves).

\section{Conclusion and limitations}

\subsection{Conclusion}

Long-term fear industries are defined as those industries that have come into existence as a result of the permanent fear of societies such as war and crime, etc. As these industries are a product of fear, so if the fear is eliminated these industries will not be required by the societies. The theory presented in this paper suggests that, in the long run, rational economies will not allow scarce resources to be allocated to long-term fear industries and will eliminate these industries in the long run. People will find ways to eliminate fears of war and crimes, or alternative ways to reduce expenditure on fear industries. Factors such as the tax break point, less resources available for non-defence expenditure and private investment, unsustainable deficit financing, foreign loans, death and destruction and a desire for free market economy, etc., will force economies to reduce and eventually eliminate these long-run fear industries. Eventually, the rational people will realize this irrational waste of resources mainly because the long run fear industry (1) reduces the investment in infrastructure, health care, food ,sheltering conditions (the possible nondefence expenditures), (2) reduces their disposable income and savings through taxes (again keep in mind that every nation has a tax break point), (3) increases inflation through deficit financing, (4) reduce market freedom and allows for more governmental intervention (sacrifices the free market economy) and (5) increases the role of foreign and international interference (foreign loans and loans taken from the IMF etc. usually come with the certain conditions) (6) incentivizes large scale death and destruction. This realization will encourage them to refuse to pay this huge opportunity cost, and even rise up in the form of riots, civil disobedience and even civil war. Governments should therefore realize this fact and start cutting spending on long-run fear industries that will eventually lead to the elimination of long-run fear industries. The developed world will initially eliminate these industries, while the developing world and the underdeveloped world will eventually eliminate their long-run fear industries by analysing the economic and social benefits that the developed world has gained from eliminating long-term fear industries. This elimination of long-term fear industries can ensure long-term peace and prosperity for the human race. Global leaders should use the UN platform to eliminate border disputes that are the main cause of international wars. There are several other alternatives, such as the elimination of borders, to ensure the free flow of human and capital resources. This can have a positive impact on global productivity by making the labour market and the product market more competitive. Joint or voluntary law enforcement under the banner of the UN, etc.

\subsection{Limitations}

\subsubsection{Rational people}

The long run elimination of the preputial fear industries is based on the assumption of economies (people) being rational in the long run, but it may also be possible that people remain irrational even in the long run. Rational choice theory asserts that people will make self-interest maximizing rational choices. But as we know through behavioural economics that it's not the case infect people decisions are influenced by irrational emotions, beliefs, superstations etc. However, as in other main stream economic theories it is also assumed in this study that the economies will evolve to be rational in the long run to eliminate the reasons for the existence of the long-run fear industries. 


\subsubsection{Sunk cost}

The elimination of perpetual fear industry could be negatively affected by the fact that many countries have invested millions of dollars in fixed assets and human capital specific to military and police goods and services. This makes it difficult for economies to consider eliminating long-run fear industries. These investments should be considered as sunk costs. For example, if we have already bought a ticket for a very bad drama or film, should we continue to waste our resources (time) just because we have already invested some money in tickets, the rational choice is to leave the drama or film and redirect our resources to other more important alternative choices, i.e. to make a rational choice by considering already invested resources as sunk cost.

\subsubsection{Terrorism}

Terrorism (non-state actors) may become a barrier to the future elimination of the long-term industry of fear (including the military and police industries). In this case, more investment in education, job creation and propaganda can ultimately help to eliminate the terrorist organizations.

\subsubsection{Defence exports}

Some major economies are exporting their defence products and services. But, as a general rule, their income from the exports of these industries is much less than the government's expenditure on these industries, which results in net expenditure on the perpetual fear industry.

\section{Appendix}

\subsection{The calculation of the SGDP and FGDP}

I will start by presenting the equation for the estimation of the GDP (gross domestic product).

$$
G D P=K+G+I+T
$$

Where GDP presents the gross domestic product of an economy, $K$ presents consumption, $G$ presents government spending, $I$ presents investment and $T$ presents net exports (exports minus imports). Economists usually prefer real $G D P$ compared to nominal $G D P$ for the estimation of the economic progress of a nation. The formula for estimating the real GDP is presented as below.

$$
\text { Real GDP }=\frac{\text { Nominal GDP }}{\text { Price inde } \div \div 00}
$$

Here the price index is divided by 100 because the published price indices are normally multiplied by 100 for the purpose of easy interpretation.

The social gross domestic product presents the GDP (nominal or real) of an economy without the long run fear industry (military and policing expenditure) from the $G D P$.

$$
S G D P=G D P-L F I
$$

Where $S G D P$ presents the social gross domestic product of an economy. GDP presents gross domestic product and $L F I$ presents the value of the long run fear industry (military and police). The free gross domestic product of a nation is presented through the following equation.

$$
F G D P=G D P-G
$$

Where $F G D P$ presents the free gross domestic product of a nation, $G$ presents all kinds of government spending for an economy.

\section{ACKNOWLEDGMENT}

This research did not receive any specific grants from public, commercial or non-profit funding agencies.

\section{REFERENCES}

1. History.com Editors, "Military-Industrial Complex," A\&E Television Networks, 2018. [Online]. Available: https://www.history.com/topics/21stcentury/military-industrial-complex. [Accessed: 24Apr-2020].

2. G. Farrell and K. Clark, "WHAT DOES THE WORLD SPEND ON CRIMINAL JUSTICE?," Helsinki, Finland, 20, 2004.

3. [3] N. Tian, A. Fleurant, A. Kuimova, P. D. Wezeman, and S. T. Wezeman, "Trends in World Military Expenditure, 2018," Solna, Sweden, 2019.

4. The White House, "A BUDGET FOR A Better America (PROMISES KEPT. TAXPAYERS FIRST.)," Washington, 2020.

5. J. Gerson, "Time to Cut the Military Budget and Fund Human Needs," Massachusetts Peace Action, 2019. [Online]. Available: https://masspeaceaction.org/time-to-cut-the-militarybudget-and-fund-human-needs/. [Accessed: 02-Jun2020].

6. Cole, "Push Back Against Trump's New Arms Race," Massachusetts Peace Action, 2020. [Online]. Available: https://masspeaceaction.org/push-backagainst-trumps-new-arms-race/. [Accessed: 02-Jun2020].

7. J. Turley, "Big money behind war: the militaryindustrial complex," Al Jazeera, 2014. [Online]. Available:

https://www.aljazeera.com/indepth/opinion/2014/01/ big-money-behind-war-military-industrial-complex20141473026736533.html. [Accessed: 02-Jun-2020].

8. D. Doonan, "NJ Anti-War Agenda Protest Against US War, \$700 Billion Military Spending Increase," Green Party US, 2017. [Online]. Available: https://www.gp.org/nj_anti_war_protest. [Accessed: 02-Jun-2020].

9. G. Gascón and T. Foglesong, "New Perspectives in 
Policing," Natl. Inst. Justice, no. Making Policing More Affordable Managing Costs and Measuring Value in Policing, p. 20, 2010.

10. S. Martinot and J. Sexton, "The Avant-Garde of White Supremacy," Soc. Identities J. Study Race, Nation Cult., vol. 9, no. 2, pp. 169-181, 2003.

11. R. Herzing, "Big Dreams and Bold Steps Toward a Police-Free Future," Truthout, 2015. [Online]. Available: https://truthout.org/articles/big-dreamsand-bold-steps-toward-a-police-free-future/. [Accessed: 23-Apr-2020].

12. [12] P. Gelderloos, "A World Without Police," CounterPunch, 2014. [Online]. Available: https://www.counterpunch.org/2014/12/29/a-worldwithout-police/. [Accessed: 23-Apr-2020].

13. C. F. Manski and D. S. Nagin, "Assessing benefits, costs, and disparate racial impacts of confrontational proactive policing," Proc. Natl. Acad. Sci., vol. 114, no. 35, pp. 9308-9313, 2017.

14. E. Hill, A. Tiefenthäler, C. Triebert, D. Jordan, H. Willis, and R. Stein, "8 Minutes and 46 Seconds: How George Floyd Was Killed in Police Custody," The New York Times Company, 2020. [Online]. Available: https://www.nytimes.com/2020/05/31/us/georgefloyd-investigation.html. [Accessed: 02-Jun-2020].

15. N. Chavez, J. Hanna, D. Andone, and M. Holcombe, "Protesters break curfew on another night of fury and frustrations over George Floyd's killing," CNN, 2020. [Online].

Available: https://www.cnn.com/2020/05/30/us/george-floydprotests-saturday/index.html. [Accessed: 02-Jun2020].

16. J. Lemire and Z. Miller, "Secret Service Rushed President Trump Into White House Bunker as Hundreds Protested Outside," Time, 2020. [Online]. Available: https://ime.com/5845891/trump-whitehouse-bunker-protests/. [Accessed: 02-Jun-2020].

17. M. R. Garfinkel, "The Economic Consequences of Reducing Military Spending," in Review (Federal Reserve Bank of St. Louis), no. November/December, Federal Reserve Bank of St. Louis, 1990, pp. 47-58.

18. M. Friedman, "Why Government is the Problem.," in Essays in Public Policy, no. 39, Stanford, California: Hoover Institution Press, 1993, pp. 1-11.

19. U. Heo, "The relationship between defense spending and economic growth in the united states," Polit. Res. Q., vol. 63, no. 4, pp. 760-770, 2015.

20. L. Farmer, "Police Misconduct Is Increasingly a Financial Issue," Governing: The Future of States and Localities, 2018. [Online]. Available: https://www.governing.com/topics/finance/govpolice-misconduct-growing-financial-issue.html. [Accessed: 23-Apr-2020].

21. E. Desli and A. Gkoulgkoutsika, "Military spending and economic growth: a panel data investigation," Econ. Chang. Restruct., 2020.

22. W. Robert and J. Alexander, "The impact of defence spending on economic growth," Def. Econ., vol. 2, no.
1, pp. 39-55, 1990.

23. S. Ando, "The Impact of Defense expenditure on Economic Growth: Panel Data Analysis Based on the Feder Model,” Int. J. Econ. Policy Stud., vol. 4, pp. 141-154, 2009.

24. L. Zhao, L. Zhao, and B. Chen, "The interrelationship between defence spending, public expenditures and economic growth: evidence from China," Def. Peace Econ., p. 16, 2015.

25. P. Chen, C. Lee, and Y. Chiu, "The nexus between defense expenditure and economic growth: New global evidence," Econ. Model., vol. 36, pp. 474-483, 2014.

26. P. Daddi, G. Agostino, and L. Pieroni, "Does military spending stimulate growth? An empirical investigation in Italy," Def. Peace Econ., no. March, p. 19, 2016.

27. C. Ortiz, R. Alvarado, and A. Salinas, "The effect of military spending on output: new evidence at the global and," Econ. Anal. Policy, vol. 62, pp. 402-414, 2019.

28. M. H. Raju and Z. Ahmed, "Effect of military expenditure on economic growth: evidences from India Pakistan and China using cointegration and causality analysis," J. Ger. Eur. Stud., vol. 4, p. 8, 2019.

29. [29] M. Friedman, "What Is Wrong with the Welfare State?," Milton Friedman Speaks (videotape publication). Hoover Institution, Standford University, New York: Harcourt Brace Jovanovich, p. Lecture delivered at the University of Rochester, 1980.

30. Rose City Copwatch, "Alternatives to Police." Rose City Copwatch, Portland, Oregon, p. 27, 2008.

31. J. Martin, "Policing is a Dirty Job, But Nobody's Gotta Do It: 6 Ideas for a Cop-Free World," Rolling Stone, 2014. [Online]. Available: https:/www.rollingstone.com/politics/politicsnews/policing-is-a-dirty-job-but-nobodys-gotta-doit-6-ideas-for-a-cop-free-world199465/\#ixzz3MAjhe2IM. [Accessed: 23-Apr-2020].

32. J. Gravelle and C. Rogers, "The Economy of Policing---The Impact of the Volunteer," Policing, vol. 4, no. 1, pp. 56-63, 2009. 